\title{
Using public-private partnerships to improve the efficiency of housing and communal services
}

\author{
Sergey Yekimov ${ }^{1 *}$ and Viktoriia Nianko $^{2}$ \\ ${ }^{1}$ Publishing House "Education and Science", 18100, Praha, Czech Republic \\ ${ }^{2}$ Dniprovsk State Technical University, 51918, Dnipropetrovsk region, Kamianske, Ukraine
}

\begin{abstract}
The attraction of private capital in the sphere of housing and communal services is widely used in economically developed countries of the world. This makes it possible to accelerate the introduction of modern innovative technologies, to take a step towards updating fixed assets and improving the efficiency of the functioning of housing and communal services enterprises. In our opinion, a very promising direction of reforming the enterprises of the housing and communal complex is the use of publicprivate partnership. The use of the public-private partnership tool makes it possible to distribute between the state and the private investor not only the profit, but also the risks associated with obtaining this profit. lose cooperation of private business with the state in the housing and communal services sector allows to reduce the level of energy consumption of this industry, increase tax revenues and achieve the transfer of the most effective innovative technologies to the municipal sector. Public-private partnerships can be important when solving problems that require private investment in the housing and utilities sector. It creates conditions for attracting investment in projects related to the functioning of housing and communal services, which are of primary importance for improving the standard of living of the population.
\end{abstract}

\section{Introduction}

Housing and communal services is a multidisciplinary industry. In this industry, there are more than 30 types of financial and economic activities.

According to [1] in Ukraine, housing and communal services have a number of specific features.

1) Many enterprises included in the housing and communal services are natural monopolists in their field of activity

2) Housing and communal services are subject to strong regulation by the state.

In the opinion of [2] housing and communal services is a complex of services and enterprises that provide public and enterprise utilities in accordance with the norms and standards.

According to [3] housing and communal services are important for the functioning and life support of settlements.

\footnotetext{
*Corresponding author: 3701313@mail.ru
} 
The authors of [4] identify the main sub-sectors of housing and communal services (Figure 1):

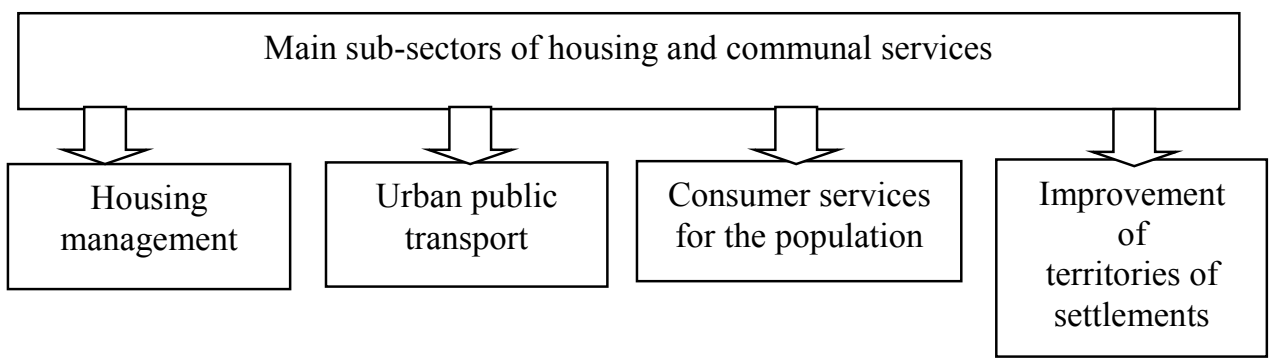

Fig. 1. Main sub-sectors of housing and communal services

In the opinion of [5] utilities have some specific features:

1. The supply of utilities must be carried out at a certain time in the required volume.

2. The consumer may not refuse to provide him with certain types of public services.

3. The supply of utilities may depend on weather and climatic factors

4. For the provision of public services, various engineering infrastructures are used, which are located on the territory where these services are provided.

According to [6] the main objectives of the functioning of housing and communal services enterprises are:

1) Providing comfortable living conditions for citizens.

2) Receiving income from economic activities.

3) Ensuring the functioning of the life support system of the locality.

4) Operation of engineering systems of settlements.

In the opinion of [7] the integral indicator of the quality of housing and communal services provided depends on (Figure 2):

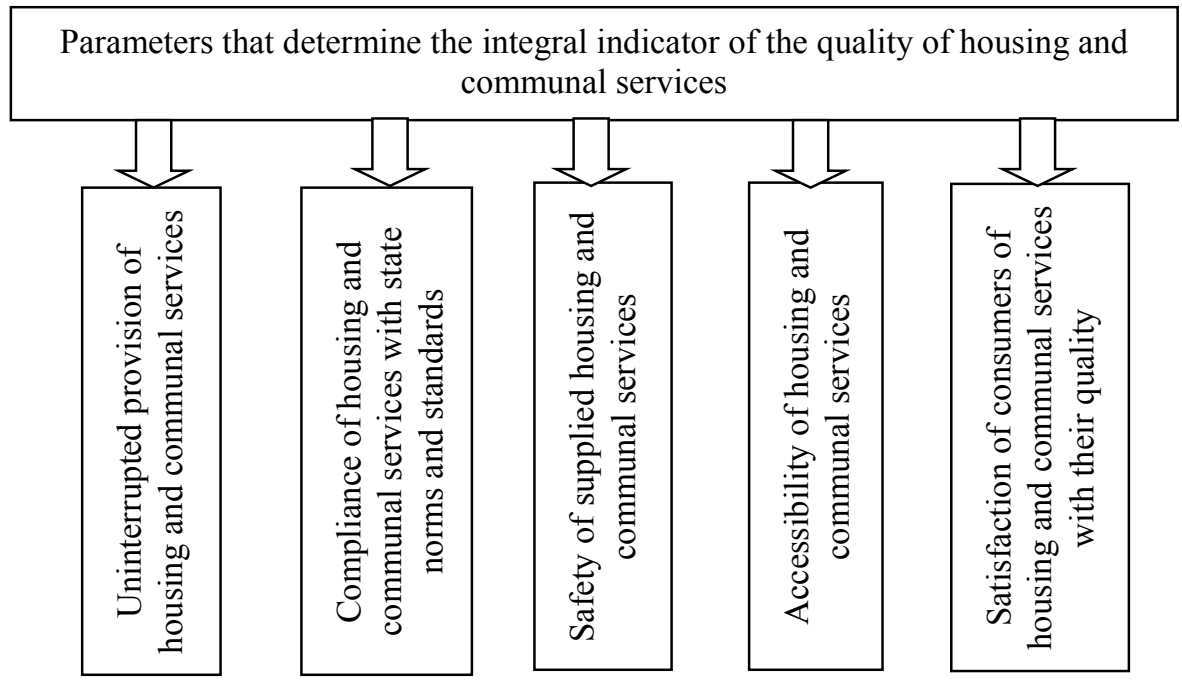

Fig. 2. Parameters that determine the integral indicator of the quality of housing and communal services

In the housing and communal services of Ukraine, in our opinion, the most important problem is the effective use of resources. Along with a low interest in reducing the consumption of electricity, water, gas and heat among users. There is a low energy efficiency in more than $65 \%$ of the housing stock. Heat losses are 1.5-2 times higher than those in industrially developed countries. 
The operation of old boiler plants leads to fuel overruns, due to the fact that they, as a rule, do not have automatic control systems for monitoring devices and operating modes. In addition, old boiler installations are more labor-intensive in their operation compared to modern counterparts.

Recycling of solid household waste remains an important problem. Most solid household waste is not sorted and processed, but is stored in places that often do not meet sanitary standards.

The development of cities increases the pressure on the environmental situation, the increase in the number of vehicles outstrips the development of the capacity of transport communications.

These problems, in our opinion, require the development and implementation of further approaches aimed at improving the functioning of the housing and communal services system.

\section{Methods}

When implementing this study, the authors used an analytical method, which allowed us to consider the problems studied in the article in their development and unity.

Taking into account the goals and objectives of this scientific research, the authors used the structural and functional method of scientific cognition.

As a result of the conducted research, we were able to study some problems related to the use of public-private partnerships in the field of housing and communal services.

\section{Results}

The formation of financial resources of municipal enterprises is associated with a number of problems. Among them, the need for state subsidies, the chronic presence of large accounts receivable from consumers of public services, and state regulation of utility tariffs have the greatest impact.

In the opinion of [8] the presence of these problems has a negative impact on the financial condition of utilities. The low level of profitability of these enterprises, as well as the moral and physical depreciation of fixed assets, require the search for new sources of financing for housing and communal services. At the moment, the main source of replenishment of the financial resources of the municipal enterprise is the income from their economic activities.

An additional source of financial resources for municipal enterprises could be bank lending [9], however, high interest rates on loans prevent this.

Thus, in our opinion, the solution to the problem of financing housing and communal services requires attracting private investment on mutually beneficial terms for the state and investors.

Authors [10] they are considering the possibility of cooperation between private business and the state in the field of housing and communal services in the form of public-private partnership.

According to the opinion [11] public-private partnerships can be applied in healthcare, transport, utilities, and energy.

The study examined the use of public-private partnerships to solve transport problems in the city of Moscow. Dnipro. The city of Dnipro covers an area of over 600 square kilometers. There are many bus routes in the city. Some of them are more than 25 kilometers long. The state municipal transport enterprise faced the problem of their unprofitability due to their length when servicing long routes, but the local authorities did not allow to increase the tariffs for the transportation of citizens. They understood the need to increase tariffs, but did not 
want to spoil relations with the voters, in their opinion, the increase in tariffs for the transportation of citizens should be well economically justified.

On the bus routes of the city of Dnipro, drivers accept payment for travel from passengers. The cost of travel on all bus routes did not depend on the distance that the passenger traveled, the fact of travel in the vehicle was paid. Initially, the state municipal transport company decided that the unprofitability of long bus routes is due to the fact that bus drivers do not hand over all the revenue received during the day at the end of the shift. Therefore, the buses were paid through plastic cards, but this did not bring much success, so the local municipal authorities asked us to solve the problem of unprofitability of long bus routes.

At the beginning of the study, we conducted a survey of bus drivers with the knowledge of the management of the state municipal transport enterprise.

The survey showed that in the opinion of bus drivers, unprofitability is due to passengers who travel long distances on buses, for this reason, especially during rush hour, bus drivers are forced to refuse transportation to other passengers, as there are not enough seats. This problem has been most exacerbated by the Covid-19 pandemic, as restrictions have been imposed on the maximum number of passengers that can be transported simultaneously in city buses.

We have proposed to introduce on some long-distance bus routes payment for travel based on the time during which the passenger uses the bus. To do this, we proposed to additionally introduce a form of payment for travel in the form of SMS messages as an experiment on some long-distance bus routes.

By sending SMS messages, the passenger could pay for the bus fare within 20 minutes. At the same time, we proposed to raise the cost of travel in these buses for passengers paying for their travel in cash or with a plastic card by $25 \%$. Since currently almost all citizens use mobile phones, the payment in the form of SMS messages for most passengers was not difficult.

However, the state-owned municipal transport enterprise could not independently implement and use it as a payment for travel on city buses via SMS messages. Therefore, a tender was held to find a private investor who would help solve this technical problem.

Due to the increase in the fare by $25 \%$, there were fewer passengers willing to travel long distances, as a result, drivers were able to serve passengers more per flight. The increase in the cost of travel, of course, reflected the costs of citizens, but the increase in these costs was objective. Those who wanted to travel longer had to pay more.

In the end, as a result of the innovations, the state-owned municipal transport company managed to achieve profitability of long-distance bus routes and is exploring the possibility of using payment for travel via SMS messages on other bus routes.

\section{Discussion}

Attracting private investment in housing and communal services has become widespread in many countries of the world. This makes it possible to accelerate the introduction of new innovative technologies, the renewal of fixed assets and the increase in the level of efficiency of housing and communal services enterprises.

In our opinion, one of the most promising areas of implementation of reforms in the field of housing and communal services is the use of public-private partnerships.

The use of the mechanism of public-private partnership allows you to distribute between the private investor and the state not only the profits, but also at the same time the risks associated with the functioning of housing and communal services.

The cooperation of private business with the state in the field of housing and communal services encourages the reduction of energy consumption in this industry, the increase in tax 
revenues and the transfer of more efficient environmental innovative technologies to the public sector.

\section{Conclusion}

Public-private partnerships can play an important role in solving various problems related to attracting investment in housing and communal services.

It allows you to attract investments in various housing and communal services projects that are of great importance for improving the quality of life of citizens, while using the skills of effective management of private investors to improve the quality of public services provided.

\section{References}

1. O. Nenakhova, North Caucasus legal vestnik 1, 87-91 (2018). 10.22394/2074-73062018-1-2-87-91.

2. V. Komarov, V. Ulanovskaia, Problems of Economic Transition 26, 18-31 (1983). 10.2753/PET1061-1991260818.

3. A. Sukhorukov, S.Yu Eroshkin, P. Vanyurikhin, S. Karabahciev, E. Bogdanova, E3S Web of Conferences 110, 02082 (2019). 10.1051/e3sconf/201911002082.

4. I. Sergeeva, O. Medvedeva, V. Vasilenok, Smart Technologies in Housing and Communal Services (2020). 10.2991/aebmr.k.200423.002.

5. Kiyomov Tukhtasinovich, Academicia: an international multidisciplinary research journal 11, 466-469 (2021). 10.5958/2249-7137.2021.00389.X.

6. E. Vikulina, Voprosy regionalnoj ekonomiki, 32, 132-140 (2017). 10.21499/2078-40232017-32-3-132-140.

7. T.I. Nikiforova, Education and Science without Limits: Fundamental and Applied Researches, 70-72 (2019). 10.36683/2500-249X-2019-10-70-72.

8. A.I. Lyga, Economics and Law, 143-154 (2019). 10.15407/econlaw.2019.02.143.

9. Yu. Sokolov, Issues of Risk Analysis 17, 10-25 (2020).10.32686/1812-5220-2020-175-10-25.

10. D. Silka, U. Shalbolova, Z. Kenzhegaliyeva, S. Egemberdiyeva, Vestnik MGSU, 836846 (2018). 10.22227/1997-0935.2018.7.836-846. 